\title{
Lactobacillus paracasei ssp. paracasei YBJ01 reduced D-galactose-induced oxidation in male Kuming mice
}

\author{
Huayi Suo, ${ }^{\dagger}$ Shanchun Liu, ${ }^{*}$ Jian Li, $\ddagger$ Yangping Ding, ${ }^{*}$ Hongwei Wang, ${ }^{*}$ Yu Zhang, ${ }^{*}$ Xin Zhao, $†{ }^{1}$ \\ and Jia-Le Song\# \\ ${ }^{*}$ College of Food Science, Southwest University, Chongqing 400715, P.R. China \\ †Chongqing Collaborative Innovation Center for Functional Food, Chongqing University of Education, Chongqing 400067, P.R. China \\ $\ddagger$ College of Life Science and Technology, Southwest Minzu University, Chengdu 610041, P.R. China \\ $\S$ College of Biological and Chemical Engineering, Chongqing University of Education, Chongqing 400067, P.R. China \\ \#Department of Nutrition and Food Hygiene, School of Public Health, Guilin Medical University, Guilin, Guangxi 541004, P.R. China
}

\begin{abstract}
We investigated in vitro and in vivo antioxidant activity of Lactobacillus paracasei ssp. paracasei YBJ01 (LPSP-YBJ01) isolated and identified from fermented yogurt. Strain LPSP-YBJ01 had stress tolerance against acidity, bile salt, and osmotic pressure. Five in vitro antioxidant assays were used to evaluate antioxidant activity of LPSP-YBJ01, which could scavenge free radicals (2,2-diphenyl-1-picrylhydrazyl and hydroxyl) and superoxide anion in vitro. In addition, strain LPSP-YBJ01 had stronger antilipid peroxidation activity and weak reducing power in vitro. We measured in vivo antioxidant activity of LPSP-YBJ01 in an oxidation mouse model induced by D-galactose injection. Strain LPSP-YBJ01 significantly increased serum superoxide dismutase (SOD), glutathione peroxidase, and total-antioxidant capability, and inhibited generation of malondialdehyde in a dose-dependent manner. In addition, strain LPSP-YBJ01 also increased the hepatic and splenic protein expressions of some antioxidant enzymes such as catalase, $\mathrm{Cu} / \mathrm{Zn}-\mathrm{SOD}$, and Mn-SOD in mice treated with D-galactose. Thus, LPSP-YBJ01 had antioxidant activity in vitro and in vivo and may be a useful probiotic.
\end{abstract}

Key words: Lactobacillus paracasei ssp. paracasei YBJ01, in vitro antioxidant, D-galactose, oxidation mice

\section{INTRODUCTION}

As the human lifespan increases, research will be focused on issues facing the elderly, such as oxidative stress, which contributes to tumors, Alzheimer's disease, type 2 diabetes, obesity, cardiovascular disease,

Received March 18, 2018.

Accepted August 8, 2018

${ }^{1}$ Corresponding authors: zhaoxin@cque.edu.cn and songjiale@glmc .edu.cn and age-related macular degeneration (Bakala et al., 2012; Badgujar et al., 2016). Under normal physiological condition, free radicals and reactive oxygen species (ROS), including superoxide anions $\left(\mathrm{O}_{2}^{-}\right)$, hydrogen peroxide $\left(\mathrm{H}_{2} \mathrm{O}_{2}\right)$, hydroxyl radicals $\left({ }^{\circ} \mathrm{OH}\right)$, and peroxynitrite $\left(\mathrm{ONOO}^{-}\right)$are generated from aerobic metabolism (Bonomini et al., 2015); however, an imbalance between endogenous antioxidants and accumulation of ROS causes oxidative stress. Chronic oxidative stress could induce degenerative disorders such as carcinogenesis, rheumatoid arthritis, atherosclerosis, neurodegenerative diseases, and Alzheimer's disease in humans (Chen et al., 2010; Callaway and Jiang, 2015; Castaneda et al., 2017). Normally, excess ROS are scavenged by endogenous antioxidants such as superoxide dismutase (SOD), glutathione peroxidase (GSH-Px), and catalase, and nonenzyme glutathione, coenzyme Q10, and uric acid and perturbations in these systems may case ROS accumulation and oxidative stress (Chen et al., 2015).

Lactic acid bacteria (LAB) are probiotics (Das and Goyal, 2015). In food manufacturing, LAB are also used as starters for food fermentation. Lactobacillus paracasei, Lactococcus lactis, and Lactobacillus plantarum isolated from fermented products, such as Brazilian kefir and a Sikkim fermented beverage, reportedly had high total antioxidant activity (Leite et al., 2015; Das and Goyal, 2015). Current research suggests diets rich in antioxidants may promote health and prevent disease (He et al., 2017). Thus, we used LAB to study antioxidants to evaluate a potential antioxidant capacity of Lactobacillus paracasei ssp. paracasei YBJ01 (LPSP-YBJ01) and explore underlying mechanisms.

\section{MATERIALS AND METHODS}

\section{Experimental Microorganism Strain}

Strain LPSP-YBJ01 was isolated from fermented yogurt (Shangrila, Yunan, China), and Lactobacillus 
bulgaricus (CCTCC AB 200048) was obtained from CCTCC (China Center for Type Culture Collection, Wuhan, Hubei, China). Pure cultures were identified according to Gram staining, cell morphology, catalase activity, and 16S rRNA sequencing. Pure cultures of LPSP-YBJ01 were stored at $-80^{\circ} \mathrm{C}$ in $25 \%$ ( vol/vol) sterile glycerol for later studies.

\section{Determination of Stress Tolerance}

In the stress tolerance assay, isolated LPSP-YBJ01 was first cultured using a De Man, Rogosa, and Sharpe (MRS) medium for $18 \mathrm{~h}$ at $37^{\circ} \mathrm{C}$. Pure-cultured LPSPYBJ01 and L. bulgaricus were centrifuged at 3,000 $\times g$ for $10 \mathrm{~min}$ at $4^{\circ} \mathrm{C}$. Collected pellets were washed twice with PBS buffer $(\mathrm{pH}$ 7.4) for later study. For the low-pH tolerance assay, LPSP-YBJ01 and L. bulgaricus cells were resuspended in normal saline and cell density was adjusted to $10^{9} \mathrm{cfu} / \mathrm{mL}$. The culture mix containing $9 \mathrm{~mL}$ of fresh artificial gastric fluid $(\mathrm{pH} 2.5$, adjusted with $\mathrm{HCl})$ and resuspended cells $(1 \mathrm{~mL})$ was incubated at $37^{\circ} \mathrm{C}$ for 0 and $3 \mathrm{~h}$. Strain LPSP-YBJ01 and $L$. bulgaricus low-pH stress was assessed using a plate count method in triplicate. Incubated resuspensions were diluted with sterile deionized water, and diluents were plated on MRS agar plates (Hopebio Co., Qingdao, China). Colony-forming units on each plate were counted after incubating for $48 \mathrm{~h}$ at $37^{\circ} \mathrm{C}$.

For the bile tolerance assay, collected pellets were resuspended in fresh artificial intestinal fluid [PBS solution containing $0,0.2,0.3$, and $0.5 \%$ (wt/vol) bile salts, $\mathrm{pH}$ 8.0] and cell density was adjusted to $1 \times 10^{9}$ $\mathrm{cfu} / \mathrm{mL}$. Resuspensions were then incubated at $37^{\circ} \mathrm{C}$ for $24 \mathrm{~h}$. Resistance to bile salts was assessed using a plate count method in triplicate.

For the osmotic stress tolerance assay, pure cultures of LPSP-YBJ01 and L. bulgaricus were inoculated at $2 \%$ (vol/vol) onto MRS agar plates containing $\mathrm{NaCl}$ at $3,4,5,6,7$, and $8 \%$ (wt/vol). After incubation for $18 \mathrm{~h}$ at $37^{\circ} \mathrm{C}$, viability of LPSP-YBJ01 and L. bulgaricus was measured using a plate count method for triplicate test.

\section{In Vitro Antioxidant Activity Assay}

In the in vitro antioxidant assay, LPSP-YBJ01 and L. bulgaricus cells were first cultured for $24 \mathrm{~h}$ at $37^{\circ} \mathrm{C}$ and then the pure culture was centrifuged at $4,000 \times$ $g$ for $15 \mathrm{~min}$ at $4^{\circ} \mathrm{C}$. Pellets were washed twice with PBS buffer ( $\mathrm{pH} 7.4)$, and then resuspended in PBS solution $(\mathrm{pH} 7.4)$ to $1.0 \times 10^{9} \mathrm{cfu} / \mathrm{mL}$. The prepared cell suspensions were divided into full-cell and intracellular cell-free extract groups. For intracellular cell-free extract preparation, pure cultures of LPSP-YBJ01 and L. bulgaricus were treated with ultrasonic cell disruptor (JY92-IIDN, Ningbo Scientz Biotechnology Co. Ltd., Ningbo, Zhejiang, China) in an ice bath. After removing cell debris by centrifugation $(10,000 \times g, 15$ min, $4^{\circ} \mathrm{C}$ ), the resulting supernatant was obtained as an intracellular cell-free extract of LPSP-YBJ01.

For the 2,2-diphenyl-1-picrylhydrazyl (DPPH) radical scavenging activity assay, $2 \mathrm{~mL}$ of DPPH $(200$ $\mu \mathrm{mol} / \mathrm{L}$ ) reagent was mixed with $2 \mathrm{~mL}$ of samples (fullcell and intracellular cell-free extracts). After $30 \mathrm{~min}$ of incubation at room temperature, the reaction mixture was centrifuged at $3,000 \times g$ for $10 \mathrm{~min}$ at $4^{\circ} \mathrm{C}$ and absorbance was measured at $517 \mathrm{~nm}$ using an ELX808 microplate reader (BioTek Instruments, Winooski, VT).

For the hydroxyl radical scavenging assay, $0.2 \mathrm{~mL}$ of samples were mixed with $1.2 \mathrm{~mL}$ of reaction solutions that contained deoxyribose $(6 \mathrm{mmol} / \mathrm{L}), \mathrm{H}_{2} \mathrm{O}_{2}(3$ $\mathrm{mmol} / \mathrm{L}), \mathrm{KH}_{2} \mathrm{PO}_{4}-\mathrm{K}_{2} \mathrm{HPO}_{4}$ buffer $(20 \mathrm{mmol} / \mathrm{L}, \mathrm{pH}$ 7.4), $\mathrm{FeCl}_{3}(400 \mu \mathrm{mol} / \mathrm{L})$, EDTA $(400 \mu \mathrm{mol} / \mathrm{L})$, and ascorbic acid $(400 \mu \mathrm{mol} / \mathrm{L})$; samples were then incubated at $37^{\circ} \mathrm{C}$ for $1 \mathrm{~h}$. One milliliter of thiobarbituric acid (TBA)-trichloroacetic acid (TCA) solution was then added to the mixture and heated at $90^{\circ} \mathrm{C}$ for 30 min. Absorbance of the reaction mixture was measured at $532 \mathrm{~nm}$ using a UV-2450S spectrophotometer (Shimadzu Corp., Kyoto, Japan).

For the superoxide anion-scavenging assay, a total reaction system included samples $(0.5 \mathrm{~mL}), 1 \mathrm{~mL}$ of Tris-HCl $(150 \mathrm{mmol} / \mathrm{L}, \mathrm{pH} 8.2), 1 \mathrm{~mL}$ of diethylenetriaminepentaacetic acid $(1 \% \mathrm{wt} / \mathrm{vol})$, and $1 \mathrm{~mL}$ of pyrogallol $(1.2 \mathrm{mmol} / \mathrm{L})$ and was incubated for $10 \mathrm{~min}$ at $25^{\circ} \mathrm{C}$. After $10 \mathrm{~min}$, the absorbance of the mixture was measured at $325 \mathrm{~nm}$ using a UV-2450S spectrophotometer (Shimadzu).

For the reducing power assay, samples $(0.5 \mathrm{~mL})$ were mixed with $0.5 \mathrm{~mL}$ of PBS $(200 \mathrm{mmol} / \mathrm{L}, \mathrm{pH} 6.6)$ and $0.5 \mathrm{~mL}$ of potassium ferricyanide $(1 \% \mathrm{wt} / \mathrm{vol})$. The mixture was incubated for $20 \mathrm{~min}$ at $50^{\circ} \mathrm{C}$ and then rapidly cooled to $20^{\circ} \mathrm{C}$; subsequently, $0.5 \mathrm{~mL}$ of TCA $(10 \% \mathrm{wt} / \mathrm{vol})$ was added. The mixture was centrifuged at $4,000 \times g$ for $10 \mathrm{~min}$ at $4^{\circ} \mathrm{C}$. The upper layer $(1 \mathrm{~mL})$ was mixed with $1 \mathrm{~mL}$ of ferric chloride $(0.1 \% \mathrm{wt} / \mathrm{vol})$ and $1 \mathrm{~mL}$ of deionized water. After $10 \mathrm{~min}$, the absorbance of the mixture was measured at $700 \mathrm{~nm}$ using a UV-2450S spectrophotometer (Shimadzu).

For the lipid peroxidation assay, $0.5 \mathrm{~mL}$ of sample was mixed with $0.5 \mathrm{~mL}$ of PBS (pH 7.4), $1 \mathrm{~mL}$ of linoleic acid, and $1 \mathrm{~mL}$ of $\mathrm{FeSO}_{4}(1 \% \mathrm{wt} / \mathrm{vol})$ and incubated for $90 \mathrm{~min}$ at $37^{\circ} \mathrm{C}$. The reaction mixture was then mixed with $0.2 \mathrm{~mL}$ of TCA $(4 \% \mathrm{wt} / \mathrm{vol})$ and $2 \mathrm{~mL}$ of TBA $(0.8 \% \mathrm{wt} / \mathrm{vol})$, incubated for $30 \mathrm{~min}$ at $100^{\circ} \mathrm{C}$, and centrifuged $\left(4,000 \times g\right.$ for $15 \mathrm{~min}$ at $\left.25^{\circ} \mathrm{C}\right)$. The 
absorbance of the mixture was measured at $532 \mathrm{~nm}$ using a UV-2450S spectrophotometer (Shimadzu).

\section{Animal Study and Grouping}

A total of 60 Kuming (KM) mice ( 7 wk of age, male, 20-25 g) were purchased from the Experimental Animal Center of Chongqing Medical University (Chongqing, China), animal permit number: SCXK (Yu) 2012-0001. All experimental KM mice were maintained in a temperature- and humidity-controlled (temperature $=25$ $\pm 2^{\circ} \mathrm{C}$, relative humidity $=50 \pm 5 \%$ ) facility with a 12-h light/dark cycle and free access to a standard rodent AIN-93G chow diet and water. Following 1 wk of adaption to the laboratory environment, all mice were randomized into 6 groups $(\mathrm{n}=10$ /group): normal, oxidation model, vitamin C, and LPSP-YBJ01 cell-treated groups [low dose $=5 \times 10^{8} \mathrm{cfu} / \mathrm{kg}(\mathbf{L})$; middle dose $=$ $5 \times 10^{9} \mathrm{cfu} / \mathrm{kg}(\mathbf{M})$; high dose: $\left.5 \times 10^{10} \mathrm{cfu} / \mathrm{kg}(\mathbf{H})\right]$. Except for normal mice, other mice were treated with an intraperitoneal injection of D-galactose $(125 \mathrm{mg} / \mathrm{kg})$ once daily for 6 wk. Normal mice were given normal saline at the same dose and frequency. The vitamin $\mathrm{C}$ group was treated with oral gavage $(200 \mathrm{mg} / \mathrm{kg})$ once daily for $6 \mathrm{wk}$. The LPSP-YBJ01 cell-treated mice were treated via oral gavage $(0.2 \mathrm{~mL}$ of LPSP-YBJ01 cell solution) once daily for $6 \mathrm{wk}$. All mice were given the same diet during the experiments. The present study was approved by the Animal Ethics Committee of Southwest University.

\section{Blood Sampling and Organ Collection}

All mice were euthanized using $\mathrm{CO}_{2}$, and blood was collected from the central vein at the end of the experiment. The collected blood was centrifuged $(3,000 \times g$, $10 \mathrm{~min}, 25^{\circ} \mathrm{C}$ ) to prepare serum. The serum samples were stored at $-80^{\circ} \mathrm{C}$ for further study. The main organs, including the heart, liver, spleen, and kidney, were removed from each mouse, weighed quickly, frozen using liquid nitrogen, and stored at $-80^{\circ} \mathrm{C}$ for further study.

\section{Histological Observations}

Five samples of liver from each mouse were subjected to histological examination. The liver tissues were fixed in 10\% (vol/vol) neutral buffered formalin, dehydrated in ethanol, and embedded in paraffin. Sections $(4-\mu \mathrm{m}$ thick) were then prepared and stained with hematoxylin and eosin. Images were acquired using a Zeiss Axioskop 2 Plus microscope (Carl Zeiss MicroImoxidation, Thornwood, NY) equipped with an AxioCam MRc5 CCD camera (Carl Zeiss).

\section{Biochemical Assay}

Serum superoxide dismutase, GSH-Px, total antioxidant capability (T-AOC), and malondialdehyde (MDA) were measured using a commercial assay kit (Cayman Chemical Co., Ann Arbor, MI) according to kit instructions. Serum high-density lipoprotein cholesterol (HDL-C), low-density lipoprotein cholesterol (LDL-C), triglyceride (TG), and total cholesterol (T-CHO) were measured using commercial assay kits (Nanjing Jiancheng Bioengineering Research Institute, Nanjing, China) according to the manufacturer's instructions (Pan et al., 2018).

\section{Protein Extraction and Western Blot Analysis}

One hundred milligrams of liver or spleen tissue samples was washed with ice-cold PBS, homogenized with ice-cold radioimmunoprecipitation assay buffer, and then centrifuged at $12,000 \times g$ for $20 \mathrm{~min}$ at $4^{\circ} \mathrm{C}$. Protein was measured using a Bio-Rad protein assay kit (Hercules, CA). For Western blot, aliquots of homogenate $(50 \mu \mathrm{g}$ of protein) were resolved with SDS-PAGE and transferred to nitrocellulose membranes (Schleicher and Schuell, Keene, NH). The blots were incubated with antibodies against catalase, $\mathrm{Cu}$ / Zn-SOD and Mn-SOD obtained from Cell Signaling Technologies (Beverly, MA) and then incubated with horseradish peroxidase-conjugated secondary antibody (Cell Signaling Technologies) for $1 \mathrm{~h}$ at room temperature. The blots were washed 3 times with PBS containing $0.05 \% \mathrm{vol} / \mathrm{vol}$ Tween 20 (PBS-T), and antibody binding was visualized with ECL (GE Healthcare Life Sciences, Little Chalfont, UK). Protein expression was quantified using ImageJ software (NIH, Bethesda, MD; http://rsb.info.nih.gov/ij/).

\section{Statistical Analysis}

All data are presented as the means \pm standard deviations. Differences between means for individual groups were assessed by one-way ANOVA and Duncan's multiple range tests. Differences were considered significant when $P<0.05$. SAS v9.1 statistical software package (SAS Institute Inc., Cary, NC) was used to perform analyses.

\section{RESULTS}

\section{Tolerance to Low pH, Bile Salts, and Sodium Chloride}

Data regarding survival of LPSP-YBJ01 and L. bulgaricus in artificial gastric fluid and growth efficiency 
of LPSP-YBJ01 and L. bulgaricus in artificial intestinal fluid show that (Figure 1) LPSP-YBJ01 is well tolerated in artificial intestinal fluid and the effect is better than L. bulgaricus (Figure 1A). Increased bile salt decreased growth efficiency, but growth occurred with $0.5 \%$ bile salt. Tolerance of LPSP-YBJ01 to $\mathrm{NaCl}$ (Figure 1B) and growth efficiency were also better than that of L. bulgaricus. Strain LPSP-YBJ01 and L. bulgaricus survivals at low $\mathrm{pH}$ are seen Figure 1C. At low $\mathrm{pH}(\mathrm{pH}=3.0)$, LPSP-YBJ01 cell counts were higher better than that of $L$. bulgaricus, which show the superiority of LPSP-YBJ01 in resisting the gastrointestinal environment effect compared to L. bulgaricus.

\section{In Vitro Antioxidant Activity of LPSP-YBJ01}

We used 5 antioxidant assays to evaluate antioxidant activity of whole LPSP-YBJ01 and L. bulgaricus cells and intracellular cell-free extracts of LPSP-YBJ01 and L. bulgaricus. Figure 2 shows whole cells had more ability to scavenge free radical (DPPH and hydroxyl radical) and superoxide anion than intracellular cell-free extracts of LPSP-YBJ01 and L. bulgaricus. In addition, whole cells had more antilipid peroxidation capacity than extracts. However, intracellular cell-free extracts of LPSP-YBJ01 had greater reducing power than LPSP-YBJ01 cells, and intracellular cell-free extracts of $L$. bulgaricus also had greater reducing power than $L$. bulgaricus cells; the antioxidant effects of LPSP-YBJ01 were better than L. bulgaricus.

\section{Body Weight of D-Galactose-Treated Mice}

As shown in Figure 3, the mice in normal group had $\mathrm{BW}$ of $49.0 \pm 5.5 \mathrm{~g}$, higher than other group, with mice in model group having the lowest BW (42.8 $\pm 0.5 \mathrm{~g})$. The vitamin C, LPSP-YBJ01-L, LPSP-YBJ01-M, and LPSP-YBJ01-H mice had BW of $46.0 \pm 5.3,43.9 \pm 0.4$, $45.4 \pm 4.5$, and $47.7 \pm 1.6 \mathrm{~g}$, respectively.

\section{Effect of LPSP-YBJ01 on Serum SOD, GSH-PX, $T$-AOC and MDA in D-Galactose-Treated Mice}

No mice died during the study and D-galactose treatment induced decreased organ weight, but this organ reduction was not significantly different from that of controls (Table 1). Compared with model mice, LPSPYBJ01 treatment increased 4 kinds of main organ indices. Following treatment with a high dose $(5 \times$ $10^{10} \mathrm{cfu} / \mathrm{kg}$ per day) of LPSP-YBJ01, the organ index increased to $6.05 \pm 0.82 \mathrm{mg} / \mathrm{g}$ in heart, $46.69 \pm 3.13$ $\mathrm{mg} / \mathrm{g}$ in liver, $2.56 \pm 0.45 \mathrm{mg} / \mathrm{g}$ in spleen, and $16.96 \pm$ $0.91 \mathrm{mg} / \mathrm{g}$ in kidney, respectively.
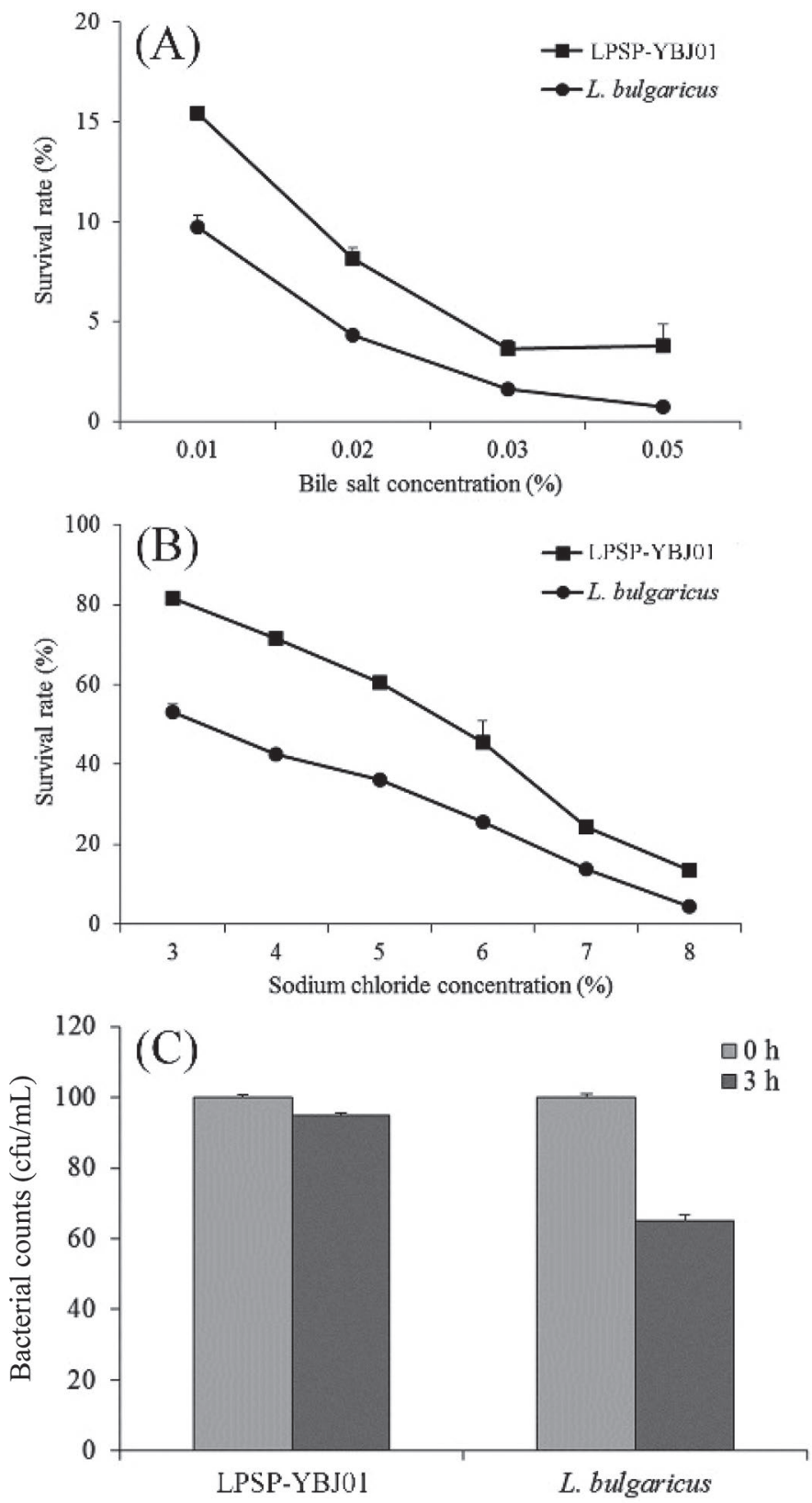

Figure 1. Tolerance (means $\pm \mathrm{SD}$ ) of Lactobacillus paracasei ssp. paracasei (LPSP) YBJ01 and Lactobacillus bulgaricus in bile salt (A), with $\mathrm{NaCl}(\mathrm{B})$, and low $\mathrm{pH}(\mathrm{C})$.

Strain LPSP-YBJ01 effects on antioxidant capacity data for D-galactose-treated mice appear in Figure 4. DGalactose treatment significantly reduced serum SOD, GSH-Px, and T-AOC $(P<0.05)$ compared with controls. Compared with D-galactose-treated mice, serum SOD of LPSP-YBJ01-treated groups were significantly increased in a dose-dependent manner $(P<0.05)$. The LPSP-YBJ01 treatment increased serum T-AOC com- 


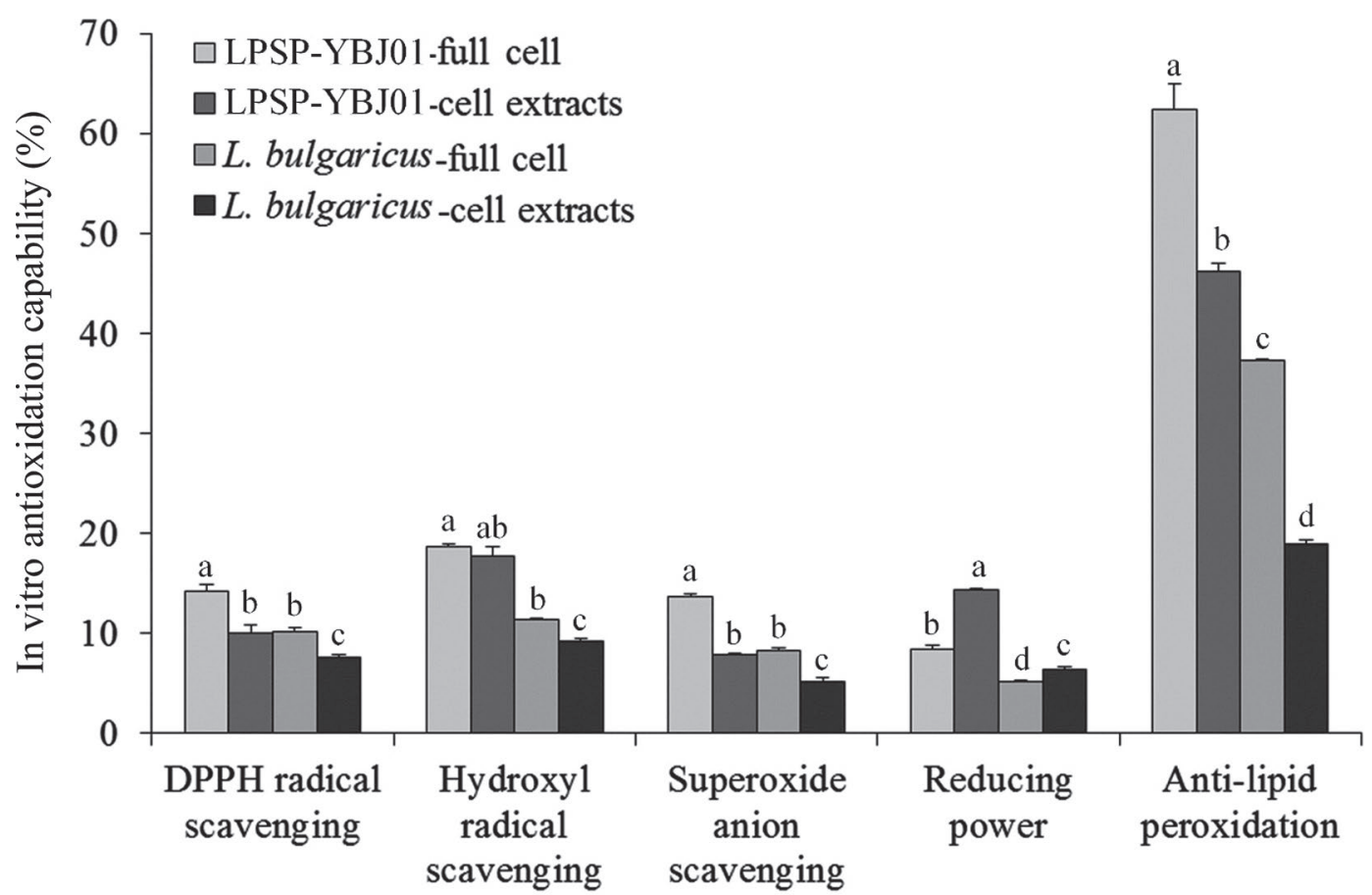

Figure 2. Antioxidant activity (means $\pm \mathrm{SD}$ ) of Lactobacillus paracasei ssp. paracasei (LPSP) YBJ01 and Lactobacillus bulgaricus in vitro. Bars with different letters $(\mathrm{a}-\mathrm{d})$ are significantly different $(P<0.05)$ according to Duncan's multiple range test. DPPH $=2,2$-diphenyl-1-picrylhydrazyl.

pared oxidation control mice $(P<0.05)$; in addition, LPSP-YBJ01 reduced serum MDA in oxidation mice but we found no significant difference between LPSP-

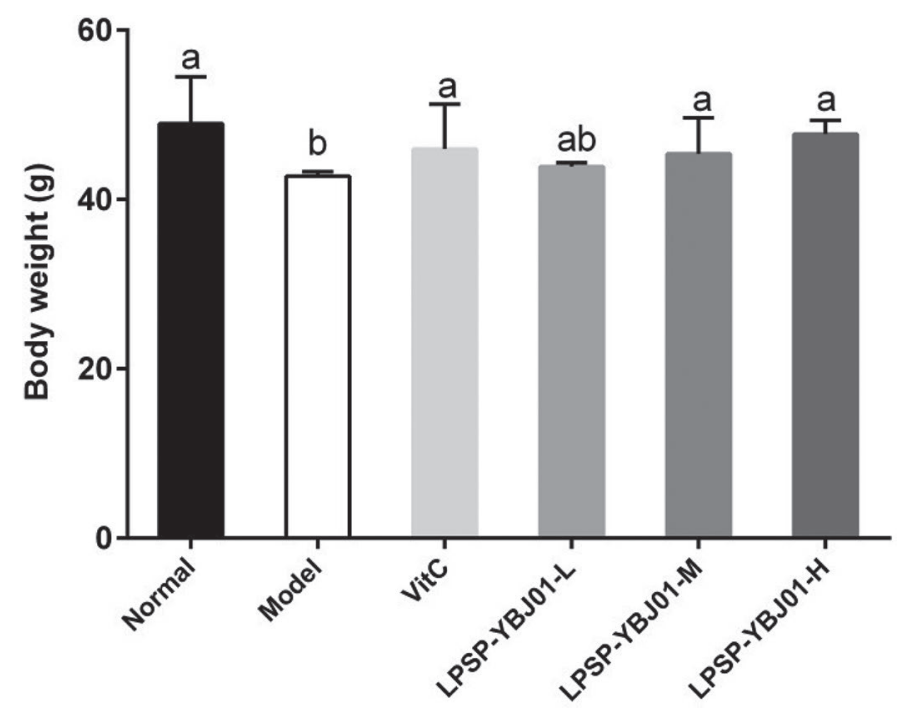

Figure 3. Body weight (means $\pm \mathrm{SD}$ ) of mice on the last day of the experiment. Bars with different letters $(\mathrm{a}, \mathrm{b})$ are significantly different $(\mathrm{P}<0.05)$ according to Duncan's multiple range test. VitC $=$ mice treated with vitamin C (200 mg/kg per day) after D-galactose injection $(125 \mathrm{mg} / \mathrm{kg}$ per day); LPSP-YBJ = mice treated with increasing doses (L, M, H) of Lactobacillus paracasei ssp. paracasei YBJ01 $(5 \times$ $10^{8}, 5 \times 10^{9}$, and $5 \times 10^{10} \mathrm{cfu} / \mathrm{kg}$ per day) after D-galactose injection.
YBJ01 strain and vitamin $\mathrm{C}$-treated mice $(P<0.05)$. Finally, LPSP-YBJ01 treatment did not change serum GSH-Px in D-galactose-treated mice.

\section{Effect of LPSP-YBJ01 on Serum TG, T-CHO, HDL-C and LDL-C in D-Galactose-Treated Mice}

Table 2 shows that D-galactose treatment significantly increased serum TG in serum oxidation mice. In the LPSP-YBJ01-treated group, TG in LPSP-YBJ01$\mathrm{L}$ was lower than that in LPSP-YBJ01-M and LPSPYBJ01-H $(P<0.05)$; D-galactose also increased serum T-CHO compared with controls. In LPSP-YBJ01 strain and with vitamin $\mathrm{C}$, serum $\mathrm{T}-\mathrm{CHO}$ decreased but we found no difference between groups $(P<0.05)$. In oxidation mice, HDL-C was the lowest of all groups. Strain LPSP-YBJ01 had higher HDL-C $(P<0.05)$ than that of the control group, but oxidation mice treated with vitamin $\mathrm{C}$ had the greatest $(P<0.05)$ HDL-C. Finally, LPSP-YBJ01 and vitamin $\mathrm{C}$ did not significantly influence serum LDL-C $(P<0.05)$.

\section{Effect of LPSP-YBJ01 on Hepatic Histological Observation in D-Galactose-Treated Mice}

Histology was used to evaluate the effect of LPSPYBJ01 strain on D-galactose-induced liver damage in 
Table 1. Effect of Lactobacillus paracasei ssp. paracasei YBJ01 on organ indices in D-galactose-treated mice ${ }^{1}$

\begin{tabular}{lcccc}
\hline Group & $\begin{array}{c}\text { Heart } \\
(\mathrm{mg} / \mathrm{g})\end{array}$ & $\begin{array}{c}\text { Liver } \\
(\mathrm{mg} / \mathrm{g})\end{array}$ & $\begin{array}{c}\text { Spleen } \\
(\mathrm{mg} / \mathrm{g})\end{array}$ & $\begin{array}{c}\text { Kidney } \\
(\mathrm{mg} / \mathrm{g})\end{array}$ \\
\hline Normal & $5.95 \pm 0.60$ & $46.53 \pm 2.43$ & $2.66 \pm 0.45$ & $16.55 \pm 2.44$ \\
Model & $4.85 \pm 0.41$ & $41.85 \pm 1.55$ & $2.49 \pm 0.88$ & $13.79 \pm 0.85$ \\
LPSP-YBJ01-L & $6.06 \pm 1.36$ & $45.08 \pm 2.70$ & $2.49 \pm 0.42$ & $15.15 \pm 2.05$ \\
LPSP-YBJ01-M & $5.56 \pm 0.65$ & $46.10 \pm 3.07$ & $2.89 \pm 0.75$ & $17.08 \pm 0.98$ \\
LPSP-YBJ01-H & $6.05 \pm 0.82$ & $46.69 \pm 3.13$ & $2.56 \pm 0.45$ & $16.96 \pm 0.91$ \\
Vitamin C & $5.76 \pm 1.36$ & $44.31 \pm 2.44$ & $2.40 \pm 0.25$ & $16.25 \pm 1.65$ \\
\hline
\end{tabular}

${ }^{1}$ Data are means \pm SD. Normal $=$ normal mice; Model $=$ mice treated with D-galactose injection; Vitamin $\mathrm{C}=$ mice treated with vitamin C (200 mg/kg per day) after D-galactose injection (125 mg/kg per day); LPSP-YBJ $=$ mice treated with increasing doses $(\mathrm{L}, \mathrm{M}, \mathrm{H})$ of Lactobacillus paracasei $\mathrm{ssp}$. paracasei YBJ01 $\left(5 \times 10^{8}, 5 \times\right.$ $10^{9}$, and $5 \times 10^{10} \mathrm{cfu} / \mathrm{kg}$ per day) after D-galactose injection.
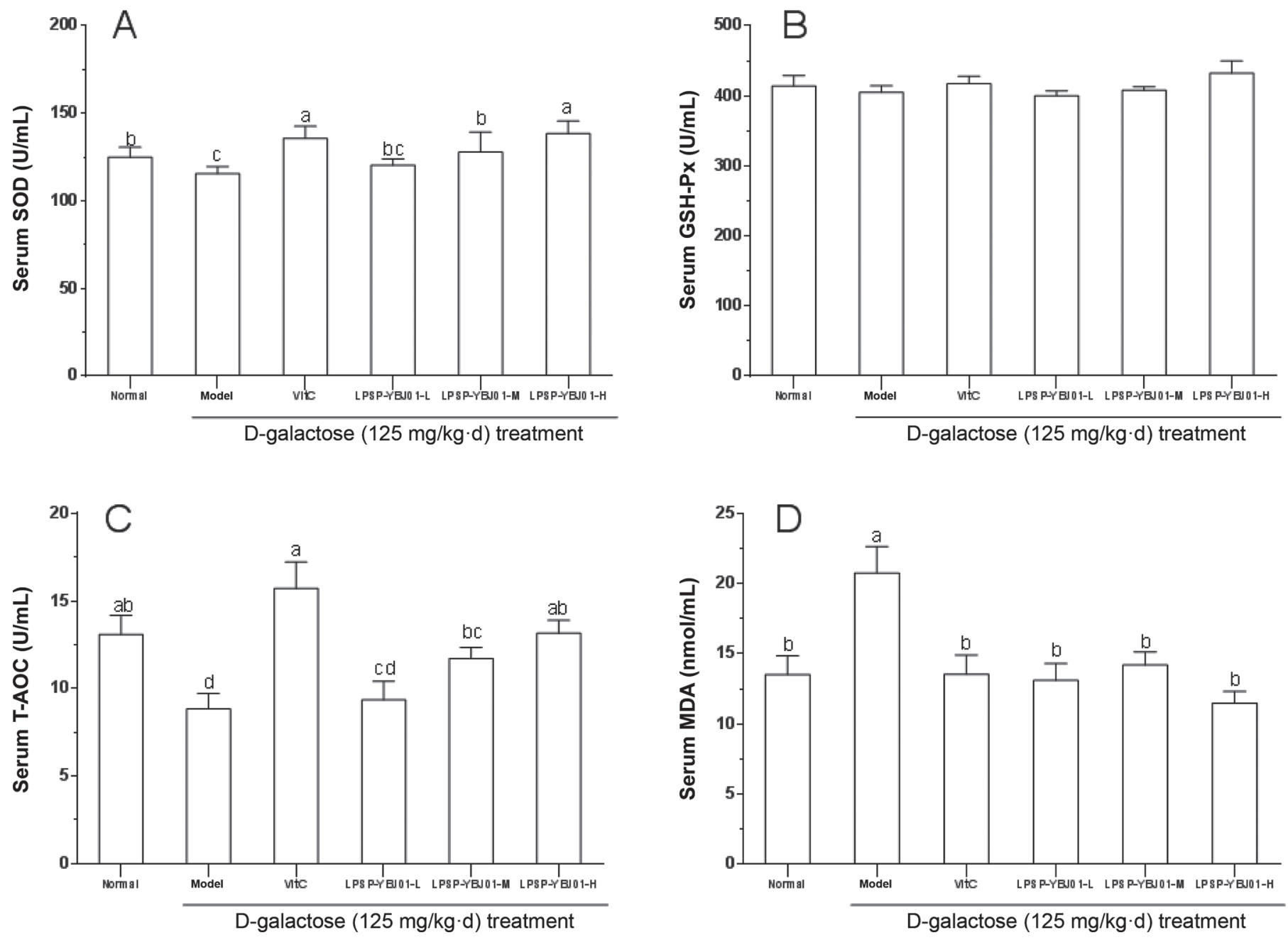

Figure 4. Effects (means $\pm \mathrm{SD}$ ) of Lactobacillus paracasei ssp. paracasei (LPSP) YBJ01 on serum superoxide dismutase (SOD; A), glutathione peroxidase (GSH-Px; B), total antioxidant capacity (T-AOC; C), and malondialdehyde (MDA; D) in D-galactose-treated mice. Bars with different letters $(\mathrm{a}-\mathrm{d})$ are significantly different $(P<0.05)$ according to Duncan's multiple range test. Normal $=$ normal mice; Model $=$ mice treated with D-galactose injection; Vitamin $\mathrm{C}=$ mice treated with vitamin $\mathrm{C}(200 \mathrm{mg} / \mathrm{kg}$ per day) after D-galactose injection $(125 \mathrm{mg} / \mathrm{kg}$ per day); LPSP-YBJ $=$ mice treated with increasing doses $(\mathrm{L}, \mathrm{M}, \mathrm{H})$ of Lactobacillus paracasei ssp. paracasei $\mathrm{YBJ}_{01}\left(5 \times 10^{8}, 5 \times 10^{9}\right.$, and $5 \times 10^{10}$ cfu/kg per day) after D-galactose injection. 
Table 2. Effect of Lactobacillus paracasei ssp. paracasei YBJ01 on serum measurements in D-galactose (125 $\mathrm{mg} / \mathrm{kg}$ per day)-treated mice ${ }^{1}$

\begin{tabular}{lcccc}
\hline Group & $\begin{array}{c}\text { TG } \\
(\mathrm{mmol} / \mathrm{L})\end{array}$ & $\begin{array}{c}\text { T-CHO } \\
(\mathrm{mmol} / \mathrm{L})\end{array}$ & $\begin{array}{c}\text { HDL-C } \\
(\mathrm{mmol} / \mathrm{L})\end{array}$ & $\begin{array}{c}\text { LDL-C } \\
(\mathrm{mmol} / \mathrm{L})\end{array}$ \\
\hline Normal & $0.88 \pm 0.06^{\mathrm{c}}$ & $2.53 \pm 0.85$ & $2.88 \pm 0.24^{\mathrm{ab}}$ & $0.28 \pm 0.09$ \\
Model & $1.59 \pm 0.35^{\mathrm{a}}$ & $3.18 \pm 0.23$ & $2.27 \pm 0.61^{\mathrm{b}}$ & $0.33 \pm 0.04$ \\
LPSP-YBJ01-L & $0.97 \pm 0.10^{\mathrm{c}}$ & $2.95 \pm 1.14$ & $2.57 \pm 0.72^{\mathrm{ab}}$ & $0.31 \pm 0.15$ \\
LPSP-YBJ01-M & $1.07 \pm 0.13^{\mathrm{bc}}$ & $3.02 \pm 0.09$ & $2.59 \pm 0.49^{\mathrm{ab}}$ & $0.31 \pm 0.11$ \\
LPSP-YBJ01-H & $1.28 \pm 0.14^{\mathrm{b}}$ & $2.83 \pm 0.65$ & $2.80 \pm 0.04^{\mathrm{ab}}$ & $0.28 \pm 0.03$ \\
Vitamin C & $1.28 \pm 0.09^{\mathrm{b}}$ & $3.04 \pm 1.23$ & $3.24 \pm 0.53^{\mathrm{a}}$ & $0.29 \pm 0.02$ \\
\hline
\end{tabular}

${ }^{\mathrm{a}-\mathrm{c} C o l u m n s}$ with different superscript letters are significantly different $(P<0.05)$ according to Duncan's multiple range test.

${ }^{1}$ Data are means $\pm \mathrm{SD} . \mathrm{TG}=$ triglyceride; $\mathrm{T}-\mathrm{CHO}=$ total cholesterol; HDL-C $=$ high-density lipoprotein cholesterol; LDL-C = low-density lipoprotein cholesterol; Normal = normal mice; Model = mice treated with D-galactose injection; Vitamin C = mice treated with vitamin C (200 mg $/ \mathrm{kg}$ per day) after D-galactose injection $(125 \mathrm{mg} / \mathrm{kg}$ per day); LPSP-YBJ = mice treated with increasing doses (L, M, H) of Lactobacillus paracasei ssp. paracasei YBJ01 $\left(5 \times 10^{8}, 5 \times 10^{9}\right.$, and $5 \times 10^{10} \mathrm{cfu} / \mathrm{kg}$ per day $)$ after D-galactose injection.

oxidation mice, and we found no significant difference in liver appearance between LPSP-YBJ01 and vitamin $\mathrm{C}$ groups and controls. Figure 5 shows that daily injection of D-galactose $(125 \mathrm{mg} / \mathrm{kg}$ per day) significantly induced visible structural damage in mice livers, and both LPSP-YBJ01 treatments reduced this chemical damage. In the vitamin C-treated group, liver damage was less severe than in controls (only D-galactose treatment) and in LPSP-YBJ01-L mice.

\section{Effects of LPSP-YBJ01 on Hepatic Catalase, Cu/Zn-SOD, and Mn-SOD Protein in Mice}

D-Galactose treatment significantly reduced hepatic catalase, $\mathrm{Cu} / \mathrm{Zn}-\mathrm{SOD}$, and $\mathrm{Mn}-\mathrm{SOD}$ protein in mice $(P$ $<0.05)$. Treatment with LPSP-YBJ01 increased $\mathrm{Cu} /$ Zn-SOD and Mn-SOD protein expression in livers of oxidation mice (Figure 6). However, catalase after the middle dose of LPSP-YBJ01 (LPSP-YBJ01-M) treat-
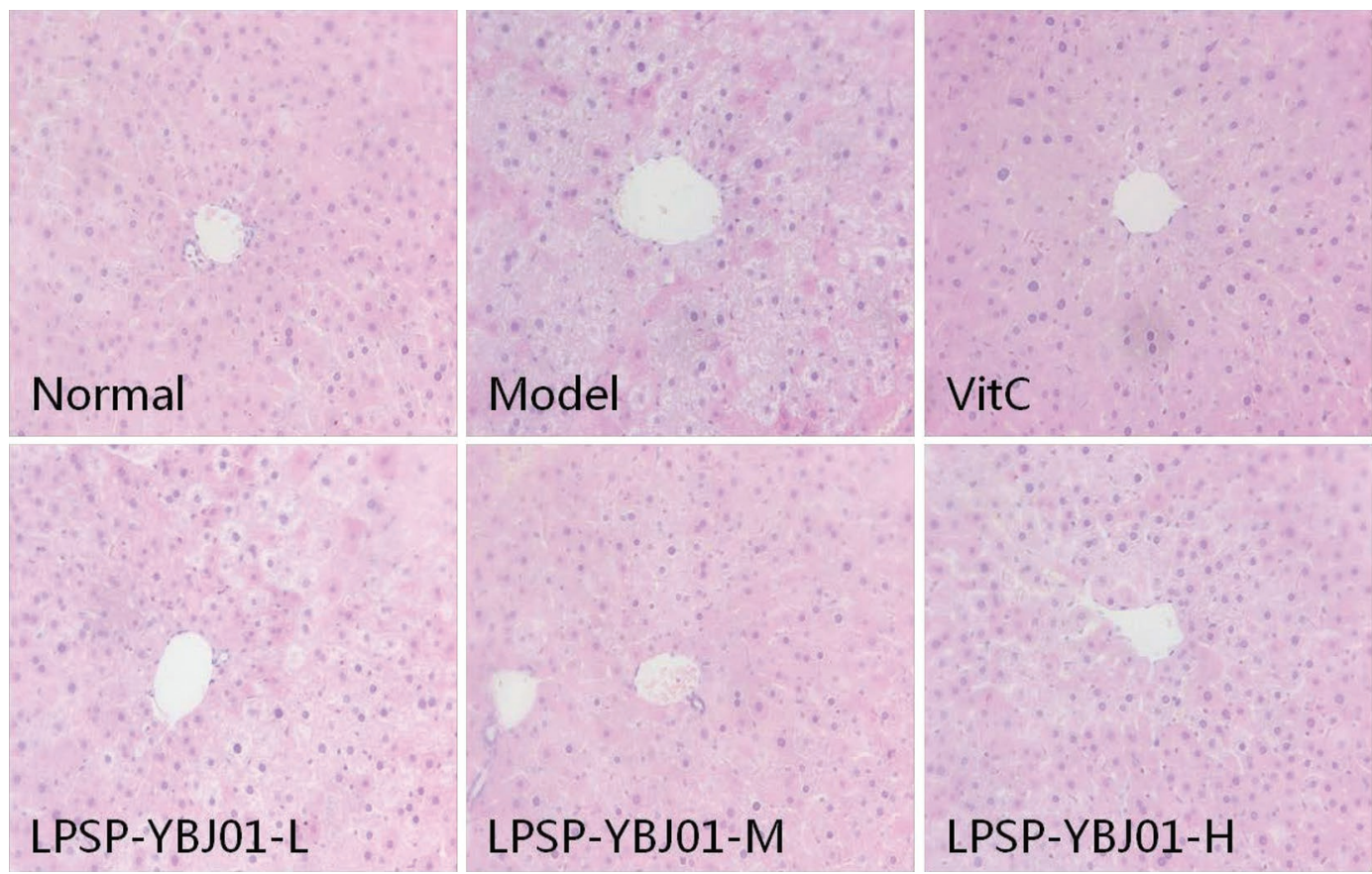

Figure 5. Effect of Lactobacillus paracasei ssp. paracasei YBJ01 on morphological changes of liver tissue in D-galactose-treated mice. Normal $=$ liver sections from controls; Model $=$ mice treated with D-galactose $(125 \mathrm{mg} / \mathrm{kg}$ per day $) ; \mathrm{VitC}=$ mice treated with vitamin $\mathrm{C}(200 \mathrm{mg} / \mathrm{kg}$ per day) after D-galactose injection; LPSP-YBJ01 = mice treated with increasing doses $(\mathrm{L}, \mathrm{M}, \mathrm{H})$ of $L$. paracasei ssp. paracasei YBJ01 $\left(5 \times 10^{8}\right.$, $5 \times 10^{9}$, and $5 \times 10^{10} \mathrm{cfu} / \mathrm{kg}$ per day) after D-galactose injection. Original magnification $100 \times$. Color version available online. 
ment was lower than in the higher and lower treatment groups. In the vitamin $\mathrm{C}$-treated group, hepatic $\mathrm{Cu} /$ Zn-SOD expression was higher than in the LPSPYBJ01-treated group. However, Mn-SOD protein in the vitamin C-treated group was lower in LPSPYBJ01-treated mice.

\section{Effects of LPSP-YBJ01 on Splenic Catalase, $\mathrm{Cu} / \mathrm{Zn}-\mathrm{SOD}$ and Mn-SOD Protein in Mice}

Figure 7 shows that D-galactose treatment significantly reduced catalase, $\mathrm{Cu} / \mathrm{Zn}-\mathrm{SOD}$, and $\mathrm{Mn}-\mathrm{SOD}$ protein in mouse spleens. Strain LPSP-YBJ01 increased splenic protein expression in oxidation mice, but Mn-SOD in LPSP-YBJ01-M was lower than in LPSP-YBJ01-L and LPSP-YBJ01-H groups. Splenic catalase, Cu/Zn-SOD, and Mn-SOD protein in vitamin C-treated groups were greater than those in LPSP-YBJ01-treated oxidation mice.

\section{DISCUSSION}

Lactic acid bacteria are key to food manufacturing and maintaining human or animal health (Laiño et al., 2015; Landete et al., 2017), and LAB strains isolated from fermented foods may have antioxidant activity (Das and Goyal, 2015; Leite et al., 2015). Thus, we focused on studying antioxidant activity of LPSP-YBJ01 strain. First, we observed that LPSP-YBJ01 was highly tolerant to low $\mathrm{pH}$ and bile salts in vitro as compared with common $L$. bulgaricus used as reference strain. These data agreed with previous studies, which suggested that $L$. paracasei strains had acid and bile salt stress tolerance (Desmond et al., 2004). In addition,
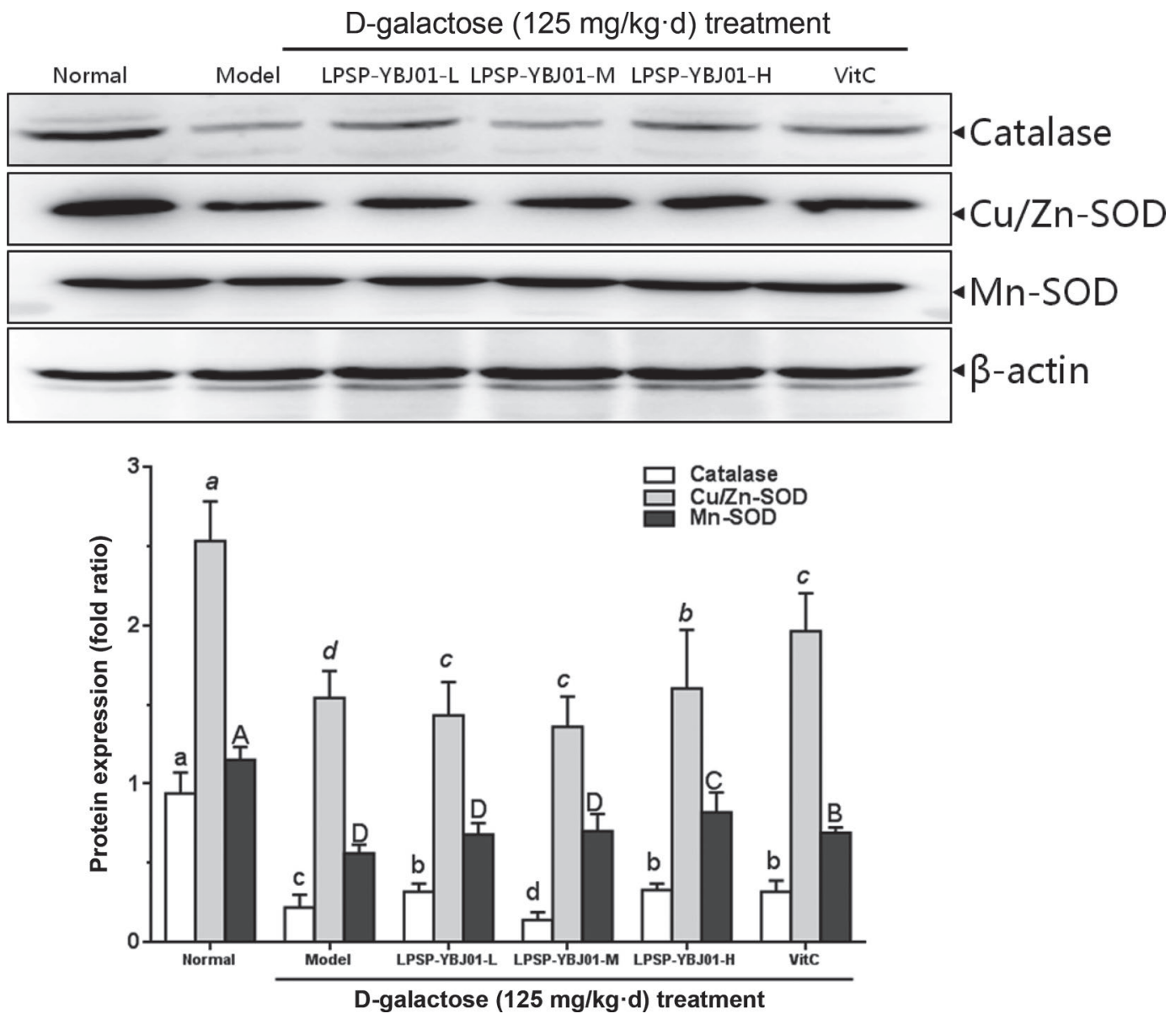

Figure 6. Effects of Lactobacillus paracasei ssp. paracasei YBJ01 on protein expression of catalase, Cu/Zn-superoxide dismutase (SOD) and Mn-SOD in the liver of Kuming (KM) mice treated with D-galactose (125 mg/kg per day). Proteins were quantified and normalized relative to $\beta$-actin (internal control). Data are expressed as means $\pm \mathrm{SD}$. Bars with different letters $(\mathrm{a}-\mathrm{d}, a-d, \mathrm{~A}-\mathrm{D})$ are significantly different $(P<0.05)$ according to Duncan's multiple range test. Normal = normal mice; Model = mice treated with D-galactose injection $(125 \mathrm{mg} / \mathrm{kg}$ per day); VitC $=$ mice treated with vitamin $\mathrm{C}(200 \mathrm{mg} / \mathrm{kg}$ per day $)$ after D-galactose injection; LPSP-YBJ01 = mice treated with increasing doses (L, M, H) of L. paracasei ssp. paracasei YBJ01 $\left(5 \times 10^{8}, 5 \times 10^{9}\right.$, and $5 \times 10^{10} \mathrm{cfu} / \mathrm{kg}$ per day $)$ after D-galactose injection. 
LPSP-YBJ01 could grow in a high- $\mathrm{NaCl}$ environment, indicating that LPSP-YBJ01 strain has tolerance to osmotic stress.

A D-galactose-induced oxidation mice model has been used to evaluate antioxidation strategies in vivo (Li et al., 2012). D-Galactose is a reducing sugar and naturally occurring substance in the body. During normal physiology, accumulation of D-galactose was completely metabolized to aldose, hydrogen peroxide, and galactose oxidase and generated oxygen-derived free radicals, superoxide anion, and other ROS. DGalactose-induced oxidation-related changes included increased generation of protein carbonyls and MDA, DNA fragmentation, antioxidant enzyme inactivation, inflammation, and apoptosis (Li et al., 2014; Nita and Grzybowski, 2016).

After the oxidative senescence of the body, a weak body could lead to weight loss (Kong et al., 2018). This was seen our study, as mice in the model group showed lower BW than that of mice in the normal group, and LPSP-YBJ01 could inhibit BW loss.

The liver is important for detoxification and health maintenance, and it is affected by ROS-induced oxidative stress. In this study, D-galactose significantly damaged hepatic structures in oxidation mice. However, when given with LPSP-YBJ01 strain, D-galactose-induced histological changes were reduced. Accumulation of ROS and free radicals is a trait of oxidation (Reinisalo et al., 2015), and both can induce dysfunction of the endogenous antioxidant system, and indirectly cause oxidative damage. Reduction of ROS and free radical accumulation may prevent and treat age-related disorders (Reiter et al., 2000). We found that D-galactose injection did not affect animal organ weight organs (heart, liver, spleen, and kidney), but it decreased SOD, GSH-Px, and T-AOC in sera of oxidation mice.
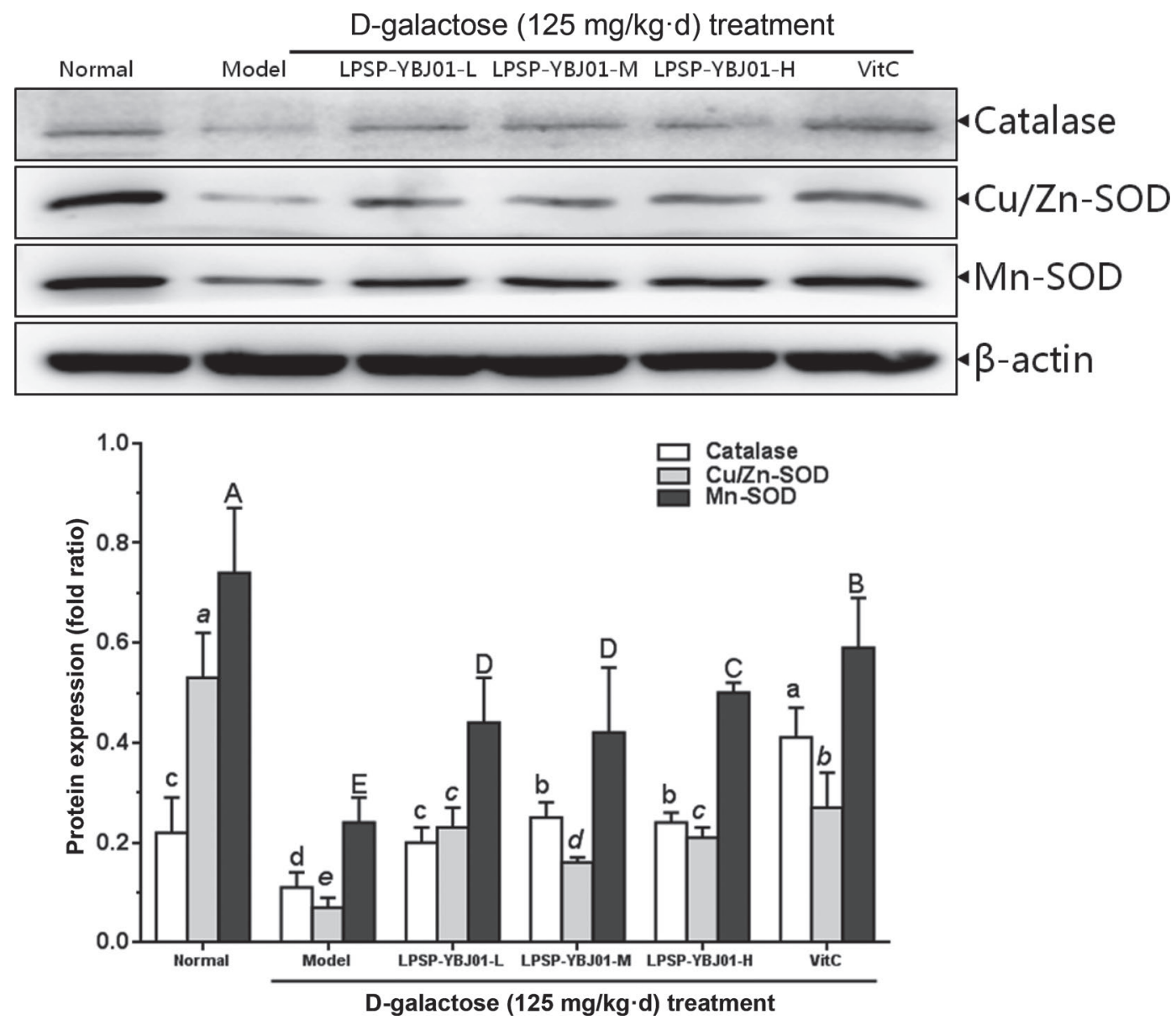

Figure 7. Effects of Lactobacillus paracasei ssp. paracasei YBJ01 on protein expression of catalase, Cu/Zn-superoxide dismutase (SOD) and Mn-SOD in the spleen of Kuming (KM) mice treated with D-galactose (125 mg/kg per day). Proteins were quantified and normalized relative to $\beta$-actin (internal control). Data are means $\pm \mathrm{SD}$. Bars with different letters $(\mathrm{a}-\mathrm{d}, a-e, \mathrm{~A}-\mathrm{E})$ are significantly different $(P<0.05)$ according to Duncan's multiple range test. Normal = normal mice; Model $=$ mice treated with D-galactose injection $(125 \mathrm{mg} / \mathrm{kg}$ per day); VitC $=$ mice treated with vitamin C (200 mg/kg per day) after D-galactose injection; LPSP-YBJ01 = mice treated with increasing doses (L, M, H) of $L$. paracasei ssp. paracasei YBJ01 $\left(5 \times 10^{8}, 5 \times 10^{9}\right.$, and $5 \times 10^{10} \mathrm{cfu} / \mathrm{kg}$ per day) after D-galactose injection. 
Strain LPSP-YBJ01 significantly increased serum SOD and T-AOC in oxidation mice. Wang et al. (2016) reported that Lactobacillus paracasei FM-LP-4 was able to increase the SOD and GSH-Px levels in main organs (liver and kidney) of D-galactose-treated mice. In addition, Lactobacillus casei Zhang treatment also increased the hepatic levels of SOD in D-galactosamine-treated rats (Wang et al., 2013). Endogenous antioxidants, such as SOD, GSH-Px, and other antioxidant enzymes (catalase, glutathione S-transferases), reduced overgenerated ROS and free radicals (Sakiyama et al., 2016); however, LPSP-YBJ01 did not change serum GSH-Px in oxidation mice. In addition, LPSP-YBJ01 strain treatment significantly reduced serum MDA in oxidation mice, which is a biomarker of membrane lipid oxidation (Sarniak et al., 2016). Our data were similar to those from other probiotic strain studies (Speakman and Selman, 2011; Wang et al., 2013, 2016; Solieri et al., 2014; Van Raamsdonk et al., 2017).

We also observed that hepatic and splenic catalase was increased in LPSP-YBJ01-treated oxidation mice. Catalase decomposes $\mathrm{H}_{2} \mathrm{O}_{2}$ to $\mathrm{H}_{2} \mathrm{O}$ and $\mathrm{O}_{2}$ in all living organisms and exhibits a protective effect against oxidative injury (Foussal et al., 2010). Increasing activity of catalase attenuated the oxidative stress-induced liver damage in mice (Lai et al., 2008). In addition, LPSP-YBJ01 strain increased protein expression of antioxidant enzymes $\mathrm{Cu} / \mathrm{Zn}-\mathrm{SOD}$ and $\mathrm{Mn}-\mathrm{SOD}$ in liver and spleen of oxidation mice, respectively. Both $\mathrm{Cu} /$ Zn-SOD and Mn-SOD are antioxidant gatekeepers and scavenge superoxide anion and other radicals (Wouters et al., 2013). Activation of $\mathrm{Cu} / \mathrm{Zn}-\mathrm{SOD}$ reduced oxidative stress induced accumulation of hepatic collagen (Ye et al., 2014), and oxidative damage and inflammation in mice (Zhang et al., 2007). Thus, LPSP-YBJ01 strain can reduce D-galactose-induced oxidative damage in livers of oxidation mice.

\section{CONCLUSIONS}

We found that LPSP-YBJ01 strain with antioxidant activity was protective against D-galactose-induced liver damage in male KM mice, and this may be due to reduced oxidative stress. Data may suggest novel insights into mechanisms underlying hepatoprotective effects of LPSP-YBJ01. More work is needed to learn whether LPSP-YBJ01 is useful for age-related disease prevention.

\section{ACKNOWLEDGMENTS}

This work was partly supported by National Key Research and Development Plan (2018YFD0502404),
Beijing, China; the People's Livelihood Science and Technology Innovation Foundation of Chongqing (cstc2015shmszx80021), Chongqing, China; the Fundamental Research Funds for the Central Universities (XDJK2016A018), Chongqing, China; and the Construction Program of Chongqing Collaborative Innovation Center for Functional Food, Chongqing University of Education (167001), Chongqing, China.

\section{REFERENCES}

Badgujar, P. C., G. A. Chandratre, N. N. Pawar, A. G. Telang, and N. P. Kurade. 2016. Fipronil induced oxidative stress involves alterations in SOD1 and catalase gene expression in male mice liver: Protection by vitamins E and C. Environ. Toxicol. 31:1147-1158.

Bakala, H., M. Hamelin, J. Mary, C. Borot-Laloi, and B. Friguet. 2012. Catalase, a target of glycation damage in rat liver mitochondria with oxidation. Biochim. Biophys. Acta 1822:1527-1534.

Bonomini, F., L. F. Rodella, and R. Rezzani. 2015. Metabolic syndrome, oxidation and involvement of oxidative stress. Aging Dis. $6: 109-120$

Callaway, D. A., and J. X. Jiang. 2015. Reactive oxygen species and oxidative stress in osteoclastogenesis, skeletal oxidation and bone diseases. J. Bone Miner. Metab. 33:359-370.

Castaneda, O. A., S. C. Lee, C. T. Ho, and T. C. Huang. 2017. Macrophages in oxidative stress and models to evaluate the antioxidant function of dietary natural compounds. J. Food Drug Anal. 25:111-118.

Chen, B., Y. Zhong, W. Peng, Y. Sun, and W. J. Kong. 2010. Agerelated changes in the central auditory system: comparison of D-galactose-induced oxidation rats and naturally oxidation rats. Brain Res. 1344:43-53.

Chen, P. J., C. H. Chiu, J. K. Tseng, K. T. Yang, and Y. C. Chen. 2015. Ameliorative effects of D-glucuronolactone on oxidative stress and inflammatory/fibrogenic responses in livers of thioacetamide-treated rats. J. Funct. Foods 14:154-162.

Das, D., and A. Goyal. 2015. Antioxidant activity and $\gamma$-aminobutyric acid (GABA) producing ability of probiotic Lactobacillus plantarum DM5 isolated from Marcha of Sikkim. Lebensm. Wiss. Technol. 61:263-268.

Desmond, C., G. F. Fitzgerald, C. Stanton, and R. P. Ross. 2004. Improved stress tolerance of GroESL-overproducing Lactococcus lactis and probiotic Lactobacillus paracasei NFBC 338. Appl. Environ. Microbiol. 70:5929-5936.

Foussal, C., O. Lairez, D. Calise, A. Pathak, C. Guilbeau-Frugier, P. Valet, A. Parini, and O. Kunduzova. 2010. Activation of catalase by apelin prevents oxidative stresslinked cardiac hypertrophy. FEBS Lett. 584:2363-2370.

He, L., T. He, S. Farrar, L. Ji, T. Liu, and X. Ma. 2017. Antioxidants maintain cellular redox homeostasis by elimination of reactive oxygen species. Cell. Physiol. Biochem. 44:532-553.

Kong, S. Z., J. C. Li, S. D. Li, M. N. Liao, C. P. Li, P. J. Zheng, M. H. Guo, W. X. Tan, Z. H. Zheng, and Z. Hu. 2018. Anti-aging effect of chitosan oligosaccharide on d-galactose-induced subacute aging in mice. Mar. Drugs 16:E181.

Lai, J. T., H. L. Fang, W. T. Hsieh, and W. C. Lin. 2008. Protective effect of a fermented substance from Saccharomyces cerevisiae on liver injury in mice caused by acetaminophen. Biosci. Biotechnol. Biochem. 72:2514-2520.

Laiño, J. E., H. Zelaya, M. Juárez del Valle, G. Savoy de Giori, and J. G. LeBlanc. 2015. Milk fermented with selected strains of lactic acid bacteria is able to improve folate status of deficient rodents and also prevent folate deficiency. J. Funct. Foods 17:22-32.

Landete, J. M., P. Gaya, E. Rodriguez, S. Langa, Á. Peirotén, M. Medina, and J. L. Arqués. 2017. Probiotic Bacteria for Healthier Oxidation: Immunomodulation and metabolism of phytoestrogens. 
BioMed Res. Int. 2017:5939818. https://doi.org/10.1155/2017/ 5939818.

Leite, A. M., M. A. Miguel, R. S. Peixoto, P. Ruas-Madiedo, V. M. Paschoalin, B. Mayo, and S. Delgado. 2015. Probiotic potential of selected lactic acid bacteria strains isolated from Brazilian kefir grains. J. Dairy Sci. 98:3622-3632. https://doi.org/10.3168/jds .2014-9265.

Li, S., Y. Zhao, L. Zhang, X. Zhang, L. Huang, D. Li, C. Niu, Z. Yang, and Q. Wang. 2012. Antioxidant activity of Lactobacillus plantarum strains isolated from traditional Chinese fermented foods. Food Chem. 135:1914-1919.

Li, Y. N., Y. Guo, M. M. Xi, P. Yang, X. Y. Zhou, S. Yin, C. X. Hai, J. G. Li, and X. J. Qin. 2014. Saponins from Aralia taibaiensis attenuate D-galactose-induced oxidation in rats by activating FOXO3a and Nrf2 pathways. Oxid. Med. Cell. Longev. 2014:320513.

Nita, M., and A. Grzybowski. 2016. The role of the reactive oxygen species and oxidative stress in the pathomechanism of the age-related ocular diseases and other pathologies of the anterior and posterior eye segments in adults. Oxid. Med. Cell. Longev. 2016:3164734.

Pan, Y., X. Long, R. Yi, and X. Zhao. 2018. Polyphenols in Liubao Tea can prevent CCl4-induced hepatic damage in mice through its antioxidant capacities. Nutrients 10:1280.

Reinisalo, M., A. Karlund, A. Koskela, K. Kaarniranta, and R. O Karjalainen. 2015. Polyphenol stilbenes: Molecular mechanisms of defence against oxidative stress and oxidation-related diseases. Oxid. Med. Cell. Longev. 2015:340520.

Reiter, R. J., D. X. Tan, C. Osuna, and E. Gitto. 2000. Actions of melatonin in the reduction of oxidative stress. A review. J. Biomed. Sci. 7:444-458.

Sakiyama, H., N. Fujiwara, Y. Yoneoka, D. Yoshihara, H. Eguchi, and K. Suzuki. 2016. Cu,Zn-SOD deficiency induces the accumulation of hepatic collagen. Free Radic. Res. 50:666-677.

Sarniak, A., J. Lipinska, K. Tytman, and S. Lipinska. 2016. Endogenous mechanisms of reactive oxygen species (ROS) generation. Postepy Hig. Med. Dosw. (Online) 70:1150-1165.
Solieri, L., A. Bianchi, G. Mottolese, F. Lemmetti, and P. Giudici 2014. Tailoring the probiotic potential of non-starter Lactobacillus strains from ripened Parmigiano Reggiano cheese by in vitro screening and principal component analysis. Food Microbiol. $38: 240-249$.

Speakman, J. R., and C. Selman. 2011. The free-radical damage theory: Accumulating evidence against a simple link of oxidative stress to ageing and lifespan. BioEssays 33:255-259.

Van Raamsdonk, J. M., I. E. Vega, and P. Brundin. 2017. Oxidative stress in neurodegenerative disease: Causation or association? Oncotarget 8:10777-10778

Wang, Y., Y. Li, J. Xie, Y. Zhang, J. Wang, X. Sun, and H. Zhang. 2013. Protective effects of probiotic Lactobacillus casei Zhang against endotoxin- and d-galactosamine-induced liver injury in rats via anti-oxidative and anti-inflammatory capacities. Int. Immunopharmacol. 15:30-37. https://doi.org/10.1016/j.intimp.2012 .10 .026 .

Wang, Y., J. Zhou, X. Xia, Y. Zhao, and W. Shao. 2016. Probiotic potential of Lactobacillus paracasei FM-LP-4 isolated from Xinjiang camel milk yoghurt. Int. Dairy J. 62:28-34. https://doi.org/10 .1016/j.idairyj.2016.07.001.

Wouters, D., N. Bernaert, N. Anno, B. Van Droogenbroeck, M. De Loose, E. Van Bockstaele, and L. De Vuyst. 2013. Application' and validation of autochthonous lactic acid bacteria starter cultures for controlled leek fermentations and their influence on the antioxidant properties of leek. Int. J. Food Microbiol. 165:121-133. https: //doi.org/10.1016/j.ijfoodmicro.2013.04.016

Ye, Y., R. Jia, L. Tang, and F. Chen. 2014. In vivo antioxidant and anti-skin-oxidation activities of ethyl acetate extraction from Idesia polycarpa defatted fruit residue in oxidation mice induced by D-galactose. Evid. Based Compl. Altern. Med. 2014:185716.

Zhang, X. L., B. Jiang, Z. B. Li, S. Hao, and L. J. An. 2007. Catalpol ameliorates cognition deficits and attenuates oxidative damage in the brain of senescent mice induced by D-galactose. Pharmacol Biochem. Behav. 88:64-72. https://doi.org/10.1016/j.pbb.2007.07 .004 . 